\title{
The Effect of Public Speaking Program for Students at Nurussalam Islamic Modern Boarding School
}

\author{
Komarudin', Zulaikah², and Hastuti Retno Kuspiyah ${ }^{3}$ \\ ${ }^{1}$ MA Terpadu Ushuluddin, Belambangan, Lampung Selatan \\ 1,2Pendidikan Bahasa Inggris STKIP Nurul Huda Sukaraja \\ 1'komaromang2288@gmail.com
}

\begin{abstract}
This research is a study of the public speaking program conducted at Nurussalam Islamic Boarding School. The purpose of this study is to know about how the Public Speaking program at Nurussalam Islamic Modern Boarding School and this research is qualitative research, in this research writer used the purposive sample, The writer only took the male students as the sample of research and with managers of the program that called as LAC and CLI, and the writer took the sample just for the students who are compulsory to speak English in public speaking, theyare from class 3 until class 5, and The techniques of collecting the data used interview, observation, and documentation. The result of this study is an interest of the student in following that program, where public speaking programs are divided into 10 clubs and conducted only in two days it's Friday and Saturday with three languages are English, Arabic, Indonesian.
\end{abstract}

Keywords: Public Speaking, Program, and Speaking

\section{INTRODUCTION}

Nowdays, Communication using English among people is needed in many factors such in business, marketing, education and in our circle, many people also make the language as their habit to make sure to another person with the purpose about meaning itself, not only for making sure but also as a duty in the activity. According to Khoo and Abidin (2014:127) assumed that English has appeared to be a universal language to link people from different backgrounds around the world. From that assumption, the writer can understand that the goals of humanity who live in this world need other people to make a good relationship with others. One of them is having good communication, As English is seen as a strong (CL) communicative language, and excellent communication skill in English is also a crucial factor when it comes to the criteria for a job application.

The effective communication for the human is speaking with understanding the meaning of the speakers, then the writer concludes that Speaking is a very important part of second language learning. The ability to communicate in a second language clearly and efficiently contributes to the success of the learner in school and success later in every phase of life. Speaking involves a sort of monitoring during and following speech production and the managing of communication under a range of external pressures (Bygate, 1998: 23 \& Basturkmen, 2002: 28).

Based on Khoo and Abidin (2014:127) defined that From the practice of public speaking, a student will be able to build up confidence in persuading others more effectively on the ideas and opinions that they would like to share. Besides, in an academic setting, being involved in public presentations and group discussions are common activities that a tertiary student needs to master.

Then they added "after the students overcome the anxiety to speak in public, through the limelight of speaking in front of others, it will also improve the motivational level of the students. As when students have the chance to present their speeches in front of their peers, observing the feedback given, this would prompt the student to be more self-motivated in getting new ideas and forming opinions to share for the next time."

Public speaking is a process and acting art of making a speech before an audience. (Nikitana 
2011:10) Then from the definition above the writer could understand that it is the process and the acting art is making a good speech in front of many audiences, and to be a good speaker should have an interesting topic as the material of speech, cause a good topic is one of art in doing a speech, so has good planning and a good step in arranging the sentences.

Therefore, the purpose of this study is to know the public speaking program and the effect of public speaking at Nurussalam Islamic Modern Boarding School.

\section{METHODOLOGY}

The writer used qualitative interpretative research and the appropriate method was descriptive survey research in the type of cross-sectional survey. Fraenkel \& Wallen (1990:332) stated that a cross-sectional survey collects the information from a sample that has been drawn from a predetermined population, and the information is collected at just one point in time. This is because the writer only described how does the program of public speaking at Nurussalam Sidogede. Based on research in Nurussalam Islamic Modern Boarding School the class was other with the other school generally, in Boarding School called class one until class six, not class VII/VIII/IXIXIXI/XII cause Nurussalam Islamic Boarding School followed Darussalam Islamic Modern Boarding School GONTOR Ponorogo.

Collecting data is very important in research because the data are used to get the result of the research. The techniques of collecting the data used by the writer are interviews, observation, documentation.

In this study, the writer used the validity technique in making an instrument with the content validity as follows: Firstly the writer consulted the advisor about the instrument with interview research, and the Second the writer took the instrument that was readymade, The Specification of Interview Instrument as follows:

The writer used a purposive sample as the sampling technique. This is the technique that is done by taking the subject not based on the strata, random or area but based on the availability of time, funds, and energy to reach a certain purpose. As the writer observes there were 17 classes for male and 19 classes for female, so the writer only took in male classes for every grade (from class three-class five), In this research, the writer took 2 students for every grade for male, the reason why the writer only took 18 people as the sample because 1)the active speaker of English begins from class three and for class six was unfollow, 2) the writer took the male students because the writer is male too, so it was forbidden to take the research at female students. 3) the writer only chose the students who are active in public speaking and less active. and 4) for the availability of time, funds, and energy in conducting the research, so the reason why the writer took purposive sampling because the writer only took for male students.

The object of the investigation is the students of Nurussalam. The technique of data analysis that the writer used are as follows; 1) all of the data collected through interviews, observation, and documentation, and 2) each data above was described as detail as the writer got.

\section{RESULT AND DISCUSSION}

Based on the writer's finding Nurussalam Islamic modern Boarding School is located in Sidogede village, Belitang subdistrict, Ogan Komering Ulu Timur district, which was built on a land area of $7.472,27 \mathrm{sq} \mathrm{km}$. Based on geographical location, it is quite far from the crowds and population, therefore, in this place, it is sufficient to meet the requirements as a place for the establishment of an educational institution because it will achieve calm in learning. The school still carries out reforestation, making school parks, and making road improvements to schools.

The boundaries of Nurusalam Islamic modern Boarding School are: The north side is the boundary by the people's house and is bordered by the guardrail outside the school, The south is the boundary by the house of the resident, The east is the boundary by irrigation and the female cottage 
building, The west is the boundary by the rice fields. The writer took this place because the location was close to the writer's place and the location was easy to reach by the writer, then, it was more efficient in the writer process.

Also as the writer found at Nurussalam Islamic Modern Boarding School, there are many agendas every day such as giving vocabularies in the morning, doing the conversation by international language, scout every Saturday, Public Speaking, sport, marching band, martial art, drama contest, hadroh, qiro, and other agenda that conditional event in a certain time. And the writer focused only on an activity that conducted at Nurussalam Islamic Boarding School it was the Public Speaking activity, where Public Speaking at Nurussalam Islamic Boarding School always conducted only in two days its Friday and Saturday with three languages are: English, Arabic, and Indonesian. With three managers as holders, they are CLI (Central Language Improvement) and 1230 students are as the members of Public Speaking.

The first observation was conducted on September, $6^{\text {th }}$ 2019. This is also the first time for seeing and observing Public Speaking activities. In this event, the writer described the activity of Public Speaking in every room of speech, found there are some students that still nervous while doing the speech in front of the audience and also some students confidently in facing other people.

The second observation was conducted on September, $7^{\text {th }}$ 2019. The writer asks CLI for the opinion about the "program". How the program and what should they do for the program of Public Speaking. They were interested to explain their program of Public Speaking which was conducted that night, from the explanation of CLI the writer knows that the Public Speaking program was amended 2 years ago, and now the program is conducted on two days they are Friday and Saturday.

The third observation was conducted on September, $27^{\text {th }}$ 2019. The writer asks the members in Boarding School they are class V-B and V-C who are the active members and less active members in Public Speaking program where the writer asks the members in Public Speaking with 5 interview instrument that was shown before, and they are as the senior members in Public Speaking activity.

The fourth observation was conducted from $28^{\text {th }}$ September- $05^{\text {th }}$ October 2019. The activity is an interview with students. Where the writer asks about their problem, their opinion in Public Speaking. The students were chosen by the writer who was active and less active, the students are enthusiastic when the writer interviewing with them. And the writer interviewed in the morning and the evening.

Based on the writer research the activity of Public Speaking was held by CLI (Central Language Improvement) and divided into 10 clubs of Public Speaking under LAC as supervisor of the activity, the central language improvement was instructed to members that before doing the speech in front of many audiences, the speaker should prepare the text to the leader of clubs which a leader hold by the senior student such as Class $V$ (five) and for the other member prepare the stage of speech together, then when the time of Public Speaking begins, the manager / CLI making the meeting before entering to the classroom.

Some advice was given to the members of Public Speaking that Public Speaking program is the important one to advance the language in Boarding School, and CLI always said that "Language is Our Crown", therefore in improving the English language / Arabic language need the practice more such as following the Public Speaking program, and as the writer observe the activity of Public Speaking program conducted every Friday and Saturday which it was three languages to perform they are: English, Arabic, Indonesian.

Every activity cannot be separated from the problem. Similarly, in Public Speaking there are also some problems faced by the CLI and members When the writer interview the CLI as the manager of Public Speaking program the writer found some problem faced by CLI they are as follow:

Firstly, Awareness of student participation in Public Speaking. Controlling the member who Dislikes following the program is the trouble of CLI to make their member like Public Speaking program the managers have instructed their member to make the activity is more fun than playing, because beside it there is much knowledge that they get although only as of the audience, but still 
there are some students won't join caused they are still a new student that never speak up in front of many audiences.

Secondly, As the writer found, in the middle of the Public Speaking activity found that the member who can't speak up in front of to speech, they will get some punishment from the manager who was a gift the authority to correct the mistaken, so CLI can't handle well to the other managers who gives the punishment which that punish can make the member rather afraid and make less confidence.

And also with the students, they have some problem in doing the speech as the writer observes they are the same trouble that the students have are: first is Low self-confidence, the problem faced by the major students is self-confidence. When students have to perform in front of the class, they feel nervous. Based on the interview, Students feel less confident when speaking in front of the class. It is natural for someone who has to speak up in public. But the manager always gives motivation to the students. The manager always says that they must enjoy the class. This is one of the motivations for the students in the Public Speaking activity.

The second is Lack of vocabulary, Based on the observation that conducted by the writer on the Public Speaking activity, the writer found that the students have a lack of vocabulary. The writer found that sometimes the students perform in front of the class, the students look confused when they found a strange word. It decreases their confidence. So, the lack of vocabulary is also one of the student's problems in speaking.

And the last is Pronunciation, Based on the observation on Thursday, $28^{\text {th }}$ September 2019, the writer found that many of the students still make mistakes in pronunciation. The students realized when they spoke English still use some mother tongue and also sometimes there were some words that still strange in their ears. So, it makes them cannot offer the statements correctly. From this problem, the students solved it by practicing to speak English fluently. Before they present their assignment, the students check it to the dictionary or ask directly to the manager, if there were some words that they did not know how to pronounce.

Therefore to solve the problems the managers have done some direction as Giving Motivation, to overcome the problem faced by students, such as the loss of confidence, the less of consistency to attend Public Speaking activity, the Manager provides motivation. The CLI gives motivation to the students in Public Speaking activity to be a spirit in following Public Speaking activity. When the CLI has given the motivation, the students become more comfortable in following the activity.

Next is giving correction and consultation there are several problems in the students' speaking skill. Some errors need to be justified by the CLI. Based on the observation, CLI is not only justifying, but the CLI also needs to have a special way to justify the members' errors as well and do not make them shy or afraid. provides evaluations to the students at the end of the activity. For example "You say ting, right? This is thought not ting." Sometimes the CLI also gave an evaluation face to face or personality guidance between the CLI and members. And the last is creating the work plan to solve the problem, the CLI made a work plan. This work plan could make the Public Speaking activity run well. The work plan was made at the beginning of the semester.

\section{The Result of the Interview}

Based on the writer's research that the writer interviewed the instrument to make the observation credible, the writer interviewed in the morning and the night, in the morning because the writer knew that the students are still fresh from their activities, and in the night because limited time in an interview in the morning. Based on the first interview with the first manager of CLI at night in multazam building the writer asked about Public Speaking, is it can help for improving student's speaking or not, Arif Cahya said that "Yes, of course, Public Speaking that we conducted here was built from the first this state, and it makes the students more confidence when they speak in front of people, I can prove it." (the interview on Friday, 06 th September 2019). And when asked is effective to influence speaking English? He said, "Yeah of course, because when they begin to 
speak up to the audience automatically they begin their English skill to make understand the audience." Arif Cahya's opinion the writer got the conclusion that Public Speaking helps improve student's speaking, and can build the students' confidence. Then the writer asked about the effort how to make the students master in English skill, and Arif said that "We can do something such as learn and memorizing the vocabularies, practicing or using the vocabularies in daily conversation and we can increase English by watching English movie and listening to an English song." (the interview on Friday, $06^{\text {th }}$ September 2019). So the writer knew that to make the students can speak English well in Public Speaking performance the managers do some activities that made the students forced to say English, such as learn and memorizing the vocabularies, practicing or using the vocabularies in daily conversation and we can increase English by watching English movie and listening to an English song.

Then based on the second manager of CLI the writer asked is there the influence for students? "He said "Yeah of course, Why? Because from Public Speaking the students can elaborate their language especially in the English language to make understand the audiences. (the interview on Friday, $06^{\text {th }}$ September 2019). And when the writer asked about the effort for making the students skill in English better, he said: "Yeah because we are one section so my answer is the same as Arif."

In the second interview with LAC which conducted at night in multazam building the writer asked about Public Speaking, is it can help for improving student's speaking or not, Mr. Jodiansyah said "As I know it is very helpful for improving student's speaking skill" And when asked is effective to influence speaking English? He said "Yeah of course, Why? Because of Public Speaking agenda force the speakers to make the statement that rational in audience mind with good skill in speaking" (interview with LAC On September, $7^{\text {th }}$ 2019). from the explanation above the writer knew that Public Speaking helps improve students' speaking skills and Public Speaking forced the students to make rational statements. In another opinion of LAC namely Mr. Ahdi Yahya he said that "Public Speaking is speaking practice, so to make better Public Speaking should has a good skill in speaking too" (interview with LAC On September, $7^{\text {th }}$ 2019). From the opinion of Mr. Ahdi Yahya Public Speaking is speaking practice, mean is Public Speaking as an easy way for the students how to improving their speaking skills.

The third interview is an interview with the senior students who are joined in Public Speaking program, they were class $\mathrm{V}$, and when the writer asked about the Fear of Public Speaking, the member said that "yes I have" and he added "I think a fear of Public Speaking because of less confidence." (Interview with Ihsan Rahmadi as member of Public Speaking On September $27^{\text {th }}$, 2019). And the second student when the writer asked the fear he said that "yes the first I have, but because of my habit my fear lost. And now I confidence." (Interview with M Willi Azhari as

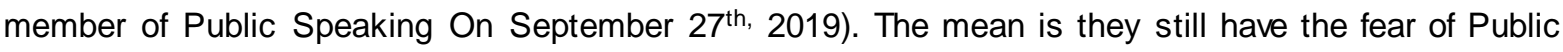
Speaking, but because of their habit of doing Public Speaking in front of people, their fear now can be lost from themselves.

The fourth interview is an interview with the members of Public Speaking, in general, they came from class four and class three, then when the writer asked about the fear of their Public Speaking they were very interested, one of them said that "No there is not, because I study speech presentation in Islamic Boarding School." And he added "Public Speaking was help me in my presentation" (interview with Didik prayogo as member of Public Speaking On October 04 $4^{\text {th }}$, 2019). Didik explanation above told about his fear if he had not a fear of Public Speaking because he has studied the speech presentation at Islamic Boarding School. On other hand said that "yes I have" he added "I think a fear of muhadoroh can less of confidence." (Interview with Suad Nurrohman as member of Public Speaking On October 05 ${ }^{\text {th }}$, 2019). Suad said (muhadoroh) not Public Speaking because he almost doesn't know what the purpose of the writer, so the writer changed by muhadoroh to make clear with the writer meant. Suad mean is by Public Speaking program the student can lack their fear. 
66 | Channing: English Language Education and Literature Vol. 4 No. 2 April 2019 Halaman: 61-69

\section{The Result of Documentation}

Based on the findings, the writer got some data. They are from the effect of the Public Speaking program, namely; 1) The First winner as speaker of English language at OKUT district in POSPEDA competition. 2) The Third winner as speaker of the English language at Palembang city in POSPENAS competition. 3) The Second winner of stand up comedy in the POSPENAS competition. 4) The First winner is the creation and reading poetry in the POSPENAS competition. 5) The First winner of Public Speaking in the English language at STIT MU. 6) The students of Public Speaking who was studying at Pare, Kediri- JATIM, and got the grade (85). 7) The students of Public Speaking who were accepted as F\&B Service / RESTAURANT WAITER. At Sahid Raya Hotels \& Convention Yogyakarta- Bintang 5. It could be seen for the following pictures.

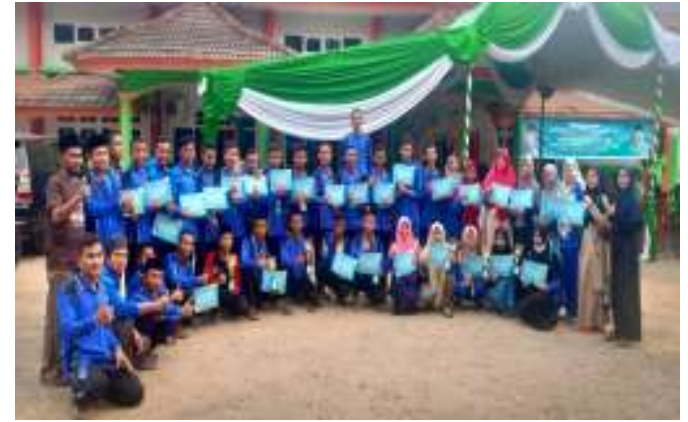

Picture 1. The First Winner Of Public Speaking Competition As English Speaker Among Senior High School In OKUT District, Zainudin Fikri. In September 2019.



Picture 2. Giving cups to the winner, and Public Speaking from Nurussalam got the Third winner. (Zainudin Fikri) on October 05 2019.

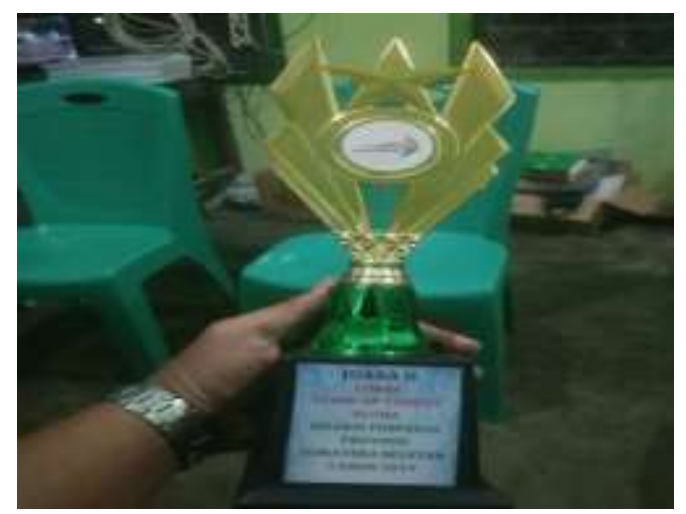

Picture 3. The Second winner of stand up comedy in the POSPENAS competition. (Dany Krisnanto) on October 06 $6^{\text {th }}, 2019$. 


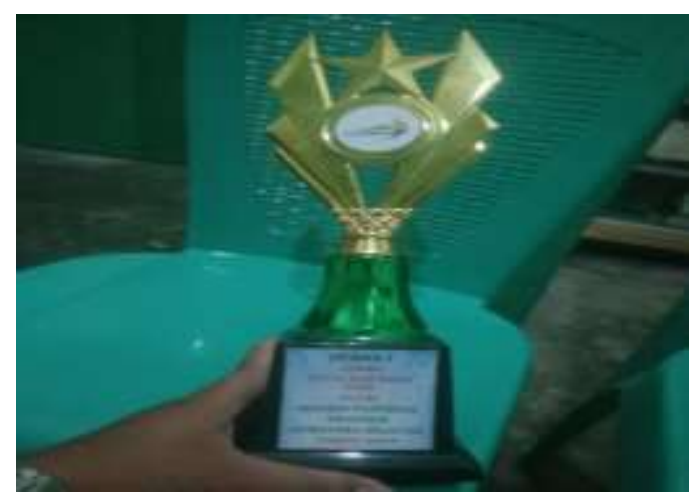

Picture 4. The First winner is the creation and reading poetry in the POSPENAS competition. (Nurul Istiqomah) on October 06 $6^{\text {th }}, 2019$.

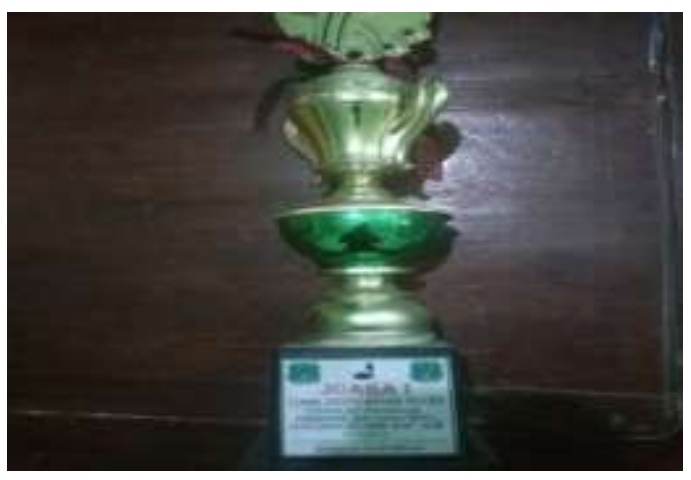

Picture 5. The first winner of Public Speaking in the English Language at STIT MU.(M Riyan Hidayat) on October $12^{\text {th }}, 2014$.

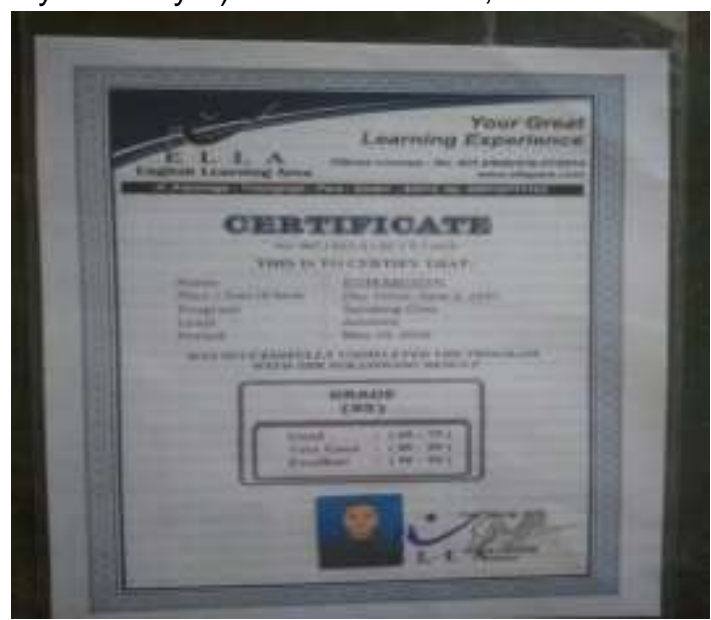

Picture 6. The students of Public Speaking who was studying at Pare, Kediri- JATIM, and got the grade (85). 




Picture 7. The students of Public speaking who were accepted as F\&B Service /

RESTAURANT WAITER. At Sahid Raya Hotels \& Convention Yogyakarta-

Bintang 5. (M Satria)

Based on the observation in the Public Speaking program, every year the students in Public Speaking activity always do that competition, and usually conduct every 6 months in a year, to know the increasing or improving students' knowledge, also to know their speaking ability. There were three CLI as the central manager of Public Speaking who handled the program run well.

Public Speaking program should be followed by all members at Nurussalam Islamic modern Boarding School male or female, for the students said (muhadoroh) in their language for easy in listening because when the writer asks Public Speaking there are some students still confused about what is the meaning, but when the writer said "muhadoroh" all of them understand the writer purpose. Then the writer interviews with basic language as they know.

Central language improvement also made the club an example for other members in Public Speaking which that club includes in some person that was got a special course to make a master's in speaking. With the club namely JMK (Jam'iatul Khutoba) where that club always performs in each club of Public Speaking to show that Public Speaking is an important skill. And according to the research, the writer asks the CLI about their program to know how the Public Speaking program that conducted at Nurussalam Islamic Boarding School.

Based on the writer research the strategy of managers in Public Speaking to make fun is making crowded situation when one of member stands in front of the audience by short song to make the speaker more confidence and making the condition live. Here are some examples of a short song that the manager show to the members " tembak tembak dia" "dor" "sekali lagi" "dor" "spirit to our brother let's together!" then all of the members clap their hand for increasing the spirit. The next strategy is making a Stand-Up comedy in the middle of speech it contents about joking with the purpose to refresh the brain of members caused half of the Public Speaking activity did in the night. It was intended to make the students happy and more interested. The CLI made the various strategies to make the activities in Public Speaking activity enjoyable. Not only tense strategies but also there was a fun strategy.

The public Speaking activity gave them a lot of knowledge especially in speaking. They were always motivated to be confident in whatever they say in front of the class, the most important thing is they want to speak up. As time goes on, they will be better.

\section{CONCLUSION}

Referring to the data analysis in the previous study which covers research finding and discussion, the writer draws some conclusion that writer research the activity of public speaking was held by CLI (Central Language Improvement) and divided into 10 clubs of public speaking under LAC as supervisor of the activity, the central language improvement was instructed to members that before doing the speech in front of many audiences, the speaker should prepare the text to the leader of 
clubs which a leader hold by the senior student such as Class $V$ (five) and for the other member prepare the stage of speech together, then when the time of public speaking begins, the manager / $\mathrm{CLI}$ making the meeting before entering to the classroom. And at Nurussalam Islamic boarding school always conducted only in two days it's Friday and Saturday with three languages are: English, Arabic, Indonesian. with three managers as holders, There are three CLI (Central Language Improvement) and there are 1230 students who are as the members of public speaking.

In the public speaking activity the CLI used some strategies there were giving a short song, and giving a stand-up comedy even in the middle of the speech, the CLI gives a suitable strategy to make the students spirit, comfortable with the activity of public speaking.

The writer also concluded that the effect of the public speaking program is very significant because helpful in improving students skill in many ways as speaking skill in front of another person, shift the lack of confidence, making more friends with each other, know the mistake of self because any the corrector, and know that learning science is more important than everything especially knowledge of the language. And also some effects of the students who have followed the Public speaking program they are:

1. The First winner as speaker of the English language at OKUT district in POSPEDA competition.

2. The Third winner as speaker of the English language at Palembang city in POSPENAS competition.

3. The Second winner of stand up comedy in POSPENAS competition.

4. The First winner is the creation and reading poetry in the POSPENAS competition.

5. The First winner of public speaking in the English language at STIT MU.

6. The students of Public Speaking who was studying at Pare, Kediri- JATIM and got the grade (85)

7. The students of Public speaking who were accepted as F\&B Service / RESTAURANT WAITER. at Sahid Raya Hotels \& Convention Yogyakarta- Bintang 5.

\section{REFERENCIES}

Bygate, M. (1998). Theoretical Perspectives On Speaking. Annual Review Of Applied Linguistics, 18, $20-42$

Jack R. Fraenkel \& Norman E. Wallen.1990. How to Design and Evaluate Research in Education.USA: McGraw-Hill.

Khoo and Abidin. (2014). The Use of Public Speaking in Motivating ESL Learners to Overcome Speech Anxiety. Malaysia: Universiti Sains Malaysia.

Nikitana, Arina. (2011). Successful public speaking. Academic transfer.

Nunan, D. (1991). Language Teaching Methodology a Textbook for Teachers. UK: Prentice-Hall International.

Raja, Farhan. (2017). Anxiety Level in Students of Public Speaking: Causes and Remedies. Institute of Business Management. 